\title{
Prawo wobec jednostki i społeczeństwa
}

Oddajemy w ręce czytelników 30 tom „Studenckich Prac Prawniczych, Ekonomicznych i Administratywistycznych" zatytułowany Prawo wobec jednostki $i$ społeczeństwa. Postępujące szybciej niż kiedykolwiek wcześniej przeobrażenia w życiu jednostek i całych społeczeństw nie mogą pozostać bez wpływu na obowiązujące normy prawne. Co więcej, coraz częstsze zmiany obowiązującego prawa lub praktyki jego stosowania również nie są bez znaczenia dla życia poszczególnych ludzi i zbiorowości. Zachodząca korelacja jest zjawiskiem trudnym do uchwycenia w jego istocie, lecz niezwykle inspirującym i fascynującym dla badaczy.

Publikacje znajdujące się w niniejszym opracowaniu na omawianą problematykę spoglądają z wielu perspektyw, co czytelnikowi daje możliwość szerszego spojrzenia na prawo, jednostkę i społeczeństwa, a w szczególności na występujące między tymi pojęciami zależności. Relacja ta jest szczególnie istotna na gruncie prawnokarnym, gdzie prawo z jednej strony chroni dobra i wartości uznane za społecznie doniosłe, a z drugiej znacząco ingeruje w sytuację osoby ludzkiej, stąd zawarte w niniejszym tomie artykuły dotyczące europejskiego nakazu aresztowania, problematyki przeszukania osoby i kontroli osobistej, a także wpływu nieskazitelności charakteru na zatarcie skazania mogą stanowić cenne źródło wiedzy z jakże ważnej materii.

Nie sposób, omawiając wpływ uregulowań normatywnych na sytuację jednostki, nie wspomnieć o kwestiach majątkowych, wciąż tak istotnych, że zdominowały życie niejednego człowieka. W aktualnym numerze mogą Państwo znaleźć opracowanie omawiające prawidłowość wdrożenia do prawa krajowego przepisów unijnych regulujących maksymalne pozaodsetkowe koszty kredytu, wobec których wciąż istnieje wiele sporów doktrynalnych i orzeczniczych. Nadto, pozostając w tematyce związanej między innymi z działalnością bankową, warto zapoznać się $\mathrm{z}$ artykułem wskazującym aktualne problemy związane z detalicznymi kredytami hipotetycznymi, które to kwestie w ostatnim czasie ponownie stały się szeroko omawiane w dyskursie publicznym. Wśród innych publikacji z zakresu prawa cywilnego w niniejszym tomie znajdują się również opracowania zajmujące się postępowaniem reprywatyzacyjnym w Polsce, postępowaniem dowodowym w sprawach mobbingowych i dyskryminacyjnych lub spojrzeniem na przyszłość prawa użytkowania wieczystego, które wciąż jest obecne w krajowych regulacjach jako ważny element polskiego prawa rzeczowego. Warto również zapoznać 
się z tekstem Parafa a podpis - linia orzecznicza, który omawia jak na z pozoru relewantną kwestię spoglądają organy stosujące prawo.

Niniejszy numer zawiera także cenne opracowanie dla administratywistów i badaczy postępowania administracyjnego omawiające koncepcje podstaw skargi kasacyjnej w postępowaniu sądowoadministracyjnym. Warto już w tym miejscu wskazać, że spojrzenie na omawianą kwestię z perspektywy prawnej znacząco odbiega od stosunku do istniejących uregulowań zauważalnego wśród jednostek niezajmujących się na co dzień stosowaniem prawa.

Nie zabrakło także tekstów mogących zainteresować czytelników zajmujących się szczegółowo prawem zabezpieczenia społecznego lub kwestiami związanymi z produktami leczniczymi. Specjalistyczne opracowania dotykające wybranych wycinków wskazanych przedmiotów mogą okazać się wielce przydatne dla naukowców i praktyków.

Zjawisko globalizacji i zbliżanie się społeczeństw do siebie, a także ułatwienia w kontaktach między jednostkami żyjącymi w stosunkowo dalekiej od siebie odległości doprowadziło do sytuacji, w której omawianie tematyki lokalnej nie może pozostać bez odpowiednio szerszego spojrzenia, stąd cennym opracowaniem zawartym w 30 tomie jest też Polityka społeczna i rozwój społeczny specjalnego regionu administracyjnego Hongkongu. Koncepcje i zasady organizacji świadczenia pomocy społecznej w Hongkongu (cz. 1).

Prawo, które powinno odzwierciedlać zmiany zachodzące w społeczeństwie, a także życie jednostek i całych środowisk, które muszą stawiać czoła coraz to nowszym regulacjom normatywnym prawdopodobnie zawsze pozostanie w kręgu zainteresowań badawczy, stąd oddając w ręce czytelników kolejny numer „Studenckich Prac Prawniczych, Ekonomicznych i Administratywistycznych", mamy nadzieję, iż zawarte w nim teksty pozwolą z różnych perspektyw spojrzeć na omawianą tematykę i staną się inspiracją do dalszych badań.

Norbert Czechowski

ORCID: 0000-0003-1639-3200

Uniwersytet Wrocławski

Opiekun naukowy (Scientific Tutor) — dr hab. Tadeusz Kocowski, prof. UWr 